UDC 656.073.7

DOI 10.26906/EiR.2021.1(80).2247

JEL: M38

\title{
EVALUATION AND REGULATION OF SOCIO-ECONOMIC EFFICIENCY OF MANAGEMENT SYSTEMS
}

\author{
Olha Komelina*, Doctor of Sciences (Economics), Professor, \\ Mariia Hunchenko**, PhD (Economics), Associate Professor, \\ National University "Yuri Kondratyuk Poltava Polytechnic"
}

*ORCID 0000-0001-9297-4985

**ORCID 0000-0003-2488-6566

(c) Komelina O., 2021.

(C) Hunchenko M., 2021.

Стаття отримана редакиією 21.03.2021 p.

The article received by the reduction 21.03.2021.

Introduction. The effectiveness of any enterprise or organization depends primarily on their ability to form and implement quality management systems. In modern economic conditions, rapid attention is paid to a set of practical tasks of organization, methods and implementation of the latest approaches to assessing the socio-economic efficiency of the management system. The implementation of the latest tools of modern management science and practice should create the conditions for effective and long-term operation of the enterprise as a whole by regulating the effectiveness of management systems at any stage of the life cycle of the enterprise or organization. In this regard, the development of scientific and practical recommendations for the approach to assessing and regulating the socio-economic efficiency of management systems is of great importance.

The results of scientific research and theoretical generalizations of the interpretation of the concept of "efficiency of the management system" is the subject of wide discussion in scientific domestic and foreign publications.

However, in the current conditions of the country's economy, the methodological basis for organizing measures to assess and regulate the socio-economic efficiency of management systems is insufficiently developed. There is also a lack of scientific and methodological developments on improving the efficiency of management systems. At the same time, the methods and forms of assessing the socioeconomic efficiency of management systems need to be improved, necessary for professionals in solving practical problems, especially when organizing work in enterprises in the framework of integrated approaches to management. All this indicates the need for thorough study, evaluation, analysis and determination of ways to regulate the effectiveness of socio-economic management systems in modern conditions.

Analysis of recent researches and publications. The urgency of developing scientific, methodological and practical recommendations for evaluating the effectiveness of enterprise management systems remains relevant, despite the existence of the ISO Management System (MSS) (example, ISO 9001:2015 Quality management system). Such developments to assess the effectiveness of enterprise management systems allows organizations to improve performance by developing specific milestones by which organizations will work to achieve their goals, as well as to increase the level of organizational culture. R.S. Andreyeva's work is devoted to solving the problems of forming a system of indicators for evaluating the activities of enterprises. Adler Yu.P., Repina V.V., Kaplana R.S., Rybalko-Rak L.A., TaranLali O.V. attempt to create a methodology for assessing the socio-economic efficiency of enterprises, taking into account the impact of not only economic, but also social and environmental factors, are now made by both Ukrainian and foreign scientists. This fact once again confirms the urgency of the problem of developing methodological approaches to assessing the socio-economic efficiency of enterprise management systems in a dynamic environment.

The purpose of the article is solving the current scientific and applied problem of developing theoretical and methodological bases for assessing and regulating the socio-economic efficiency of the enterprise management system, as well as practical recommendations for their implementation. 
Results. Analysis of modern theoretical research has shown that today, unfortunately, there is no universal approach to assessing the socio-economic efficiency of the management system. This is due to a number of reasons. In particular, some authors propose to use indicators of production and economic activity, such as output, profit, cost, capital investment, etc., to measure the socio-economic efficiency of management systems. This approach allows to take into account the peculiarities of production, for example, the quality of technological processes, the scale and level of specialization and cooperation, the requirements for the quality of manufactured products that directly affect the volume, quality and results of management.

At the same time, many researchers believe that the socio-economic efficiency of the enterprise management system can and should be measured not only by the final results of production, but also by the direct results of the management itself. In this regard, some literature sources note the need to develop appropriate indicators for evaluating the effectiveness of enterprise management. According to another approach, the direct result of management activities is assessed by the degree or level of achievement of goals relevant to the subjects of management. To achieve the goals, the subject of management must perform certain functions and selected on their basis sets of works, individual works, operations, which in the most general form are defined as actions. Accordingly, socio-economic efficiency is often determined in two ways: by the quantity and quality of information produced by the subject of management (information approach) and by the level of organization of production and management (effective approach).

Another approach to measuring the socio-economic efficiency of the management system is used when considering it as one of many interrelated factors of increasing production efficiency. Internal changes that occur in connection with the improvement of the quality of management affect the object of management and the results of its operation.

In most scientific works in this area, the measurement of socio-economic efficiency of the management system is carried out by the level of quality obtained as a result of improving the production management system. Quality can be expressed by an indicator that reflects the total production effect of management improvement, or increase in profits, profitability, and productivity by improving the quality of management.

In some works, the improvement of management is identified by factor analysis. On the basis of economic and statistical methods quantitative dependences between final results of industrial and economic activity and the indicators reflecting a condition of management are traced. As indicators of management are used, for example, the level of organization of managerial work, the level of management technology and mechanization of management works [5, p. 11].

According to some authors, modern forms of assessing the quality of the management system require consideration of many factors, so quality indicators should better reflect the use of fixed assets and capacity; increasing the efficiency of capital investments; efficient use of human resources (increasing productivity); reduction of working time losses; mechanization of labor-intensive and auxiliary works; scientific organization of labor and management.

On this basis, the assessment of socio-economic efficiency of the enterprise management system is proposed to be carried out using a system of indicators. This system of indicators must meet the following conditions:

- reflect the costs of all types of resources consumed by the enterprise;

- create preconditions for identifying reserves to increase the efficiency of conduct;

- stimulate the use of all resources available at the enterprise;

- provide information on the effectiveness of all levels of the management hierarchy;

- perform a criterion function, i.e. for each of the indicators must be defined rules for the integration of their values

The effectiveness of any of the enterprises depends on how its main components interact with each other and on the extent to which each of them affects the others. Among the main elements of enterprise management as an open system, having the largest impact on its quality, there are such: labor resources (personnel), business processes and production technology. Therefore, to assess the socio-economic efficiency of the management system, it is advisable to consider and analyze the components of the managed and control management subsystems, and the company is considered in the logic of a systematic approach to management. Schematic representation of the general process of functioning of the enterprise as an open system is shown in Fig. 1.

Obviously, the company acts as the only mechanism that has input, means of transformation and output. At the same time, the company interacts with the external environment, carries out the process of functioning and transforms available resources into products and services. Among other factors, the organization of management at enterprises has the greatest influence, the functional features of which include 
control over production technology and support of management processes. A clear balance of management components contributes to the process of normal functioning and stable development of enterprises.

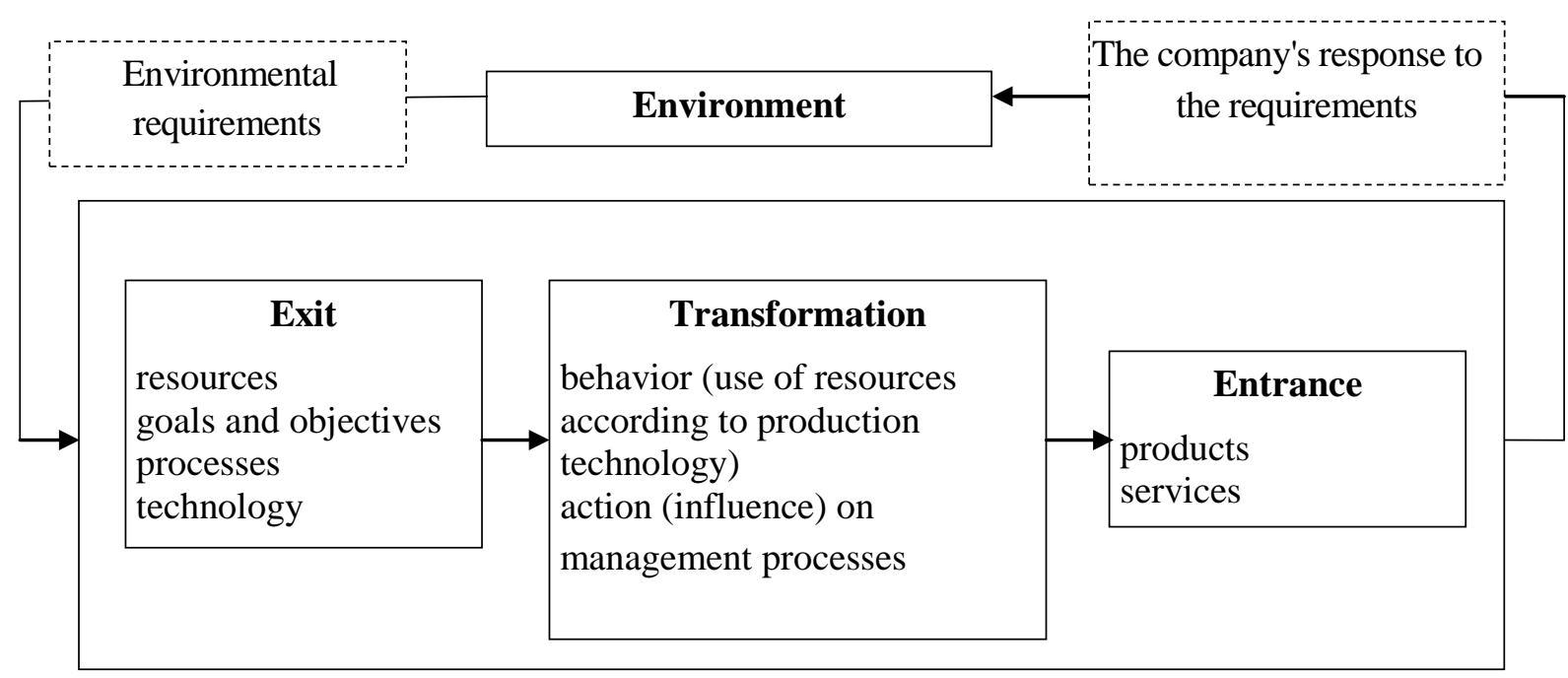

Fig. 1. The process of functioning of the enterprise as an open system

The management system of the enterprise includes two main interdependent components: the object of management production and economic activity, labor cooperation of various scales and the subject of management - the body that exerts influence on the object of management. Both components have their own structure, content and are in constant interaction.

It is important to understand that both the object and the subject of management consist of human resources, and therefore management and production staff are central factors in any model of management.

Today, two approaches to performance measurement dominate: a quantitative approach based on financial indicators, and an approach using the success factors of a strategy or business model. In the first case, the system of key performance indicators is based on the disaggregation of key financial indicators of the company and its management units and the consolidation of responsibility for individual elements in the organizational units of lower management. However, the above characteristics of the components of management gives grounds to argue about the need to distinguish and the feasibility of theoretical and methodological development of an approach to assessing the quality of management, based on the analysis of the components of the object and the subject of management.

Preserving the logic of a systematic approach to understanding the nature and content of the enterprise, we propose to summarize the indicators of socio-economic efficiency of the management system in accordance with the structural components of the control and managed subsystems.

Fig. 2 and Fig. 3. show the results of such a generalization.

The assessment of socio-economic efficiency of the management system can be carried out on the basis of various economic, social, technical and technological, financial and other indicators. The proposed system of indicators of socio-economic efficiency of the management system gives, including a comprehensive assessment of the use of all resources of the enterprise and contains all general economic indicators. Variation of the selected indicators makes it possible to make universal the proposed approach to assessing the socio-economic efficiency of the management system, to adapt it to any enterprise and its field of activity.

Conclusions. Thus, consideration of socio-economic efficiency of the management system, which is a condition for the effective functioning of the enterprise as an open system, logically leads to the need to express the result of management activities through the assessment of the system of parameters characterizing the functioning or state of the management system. 


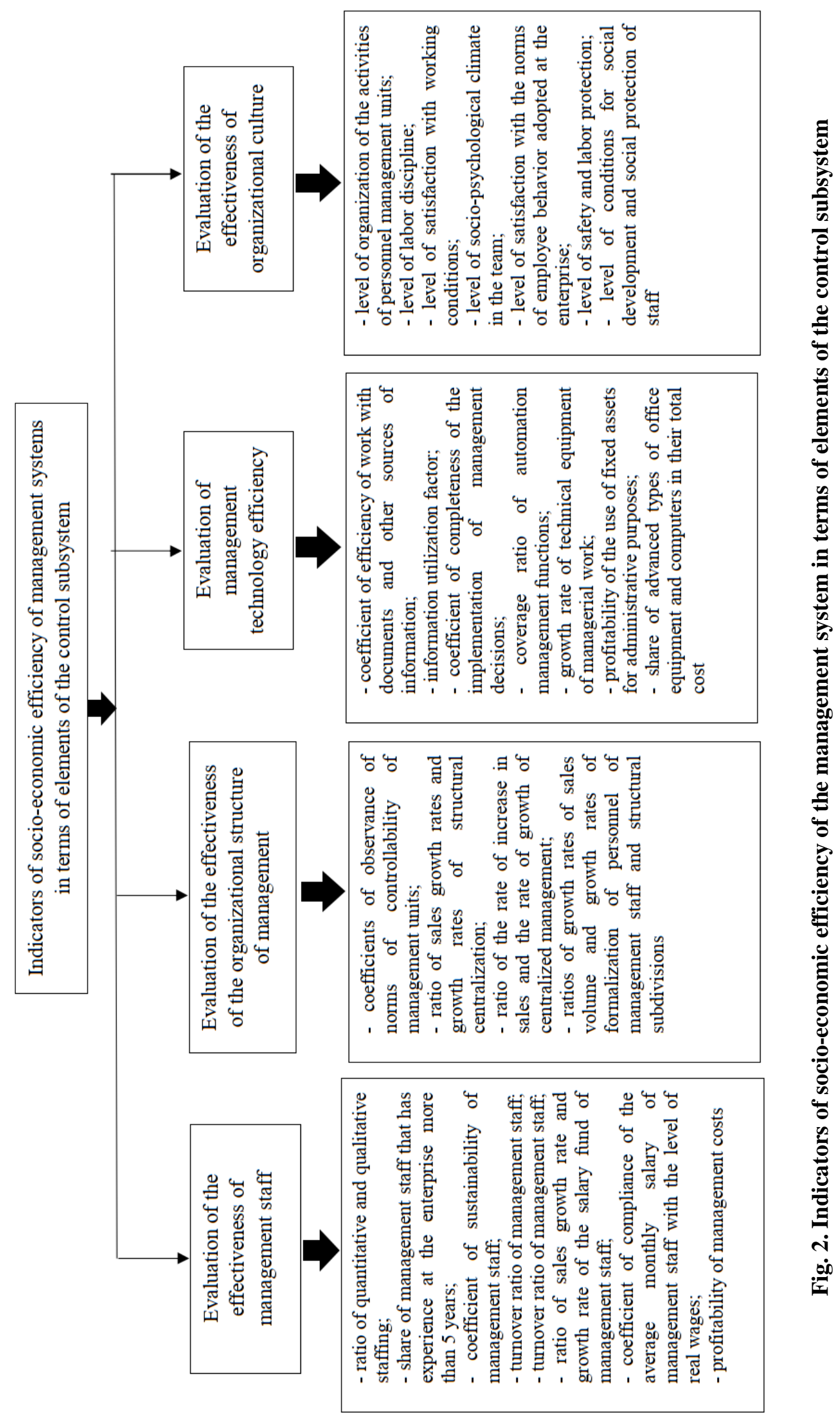




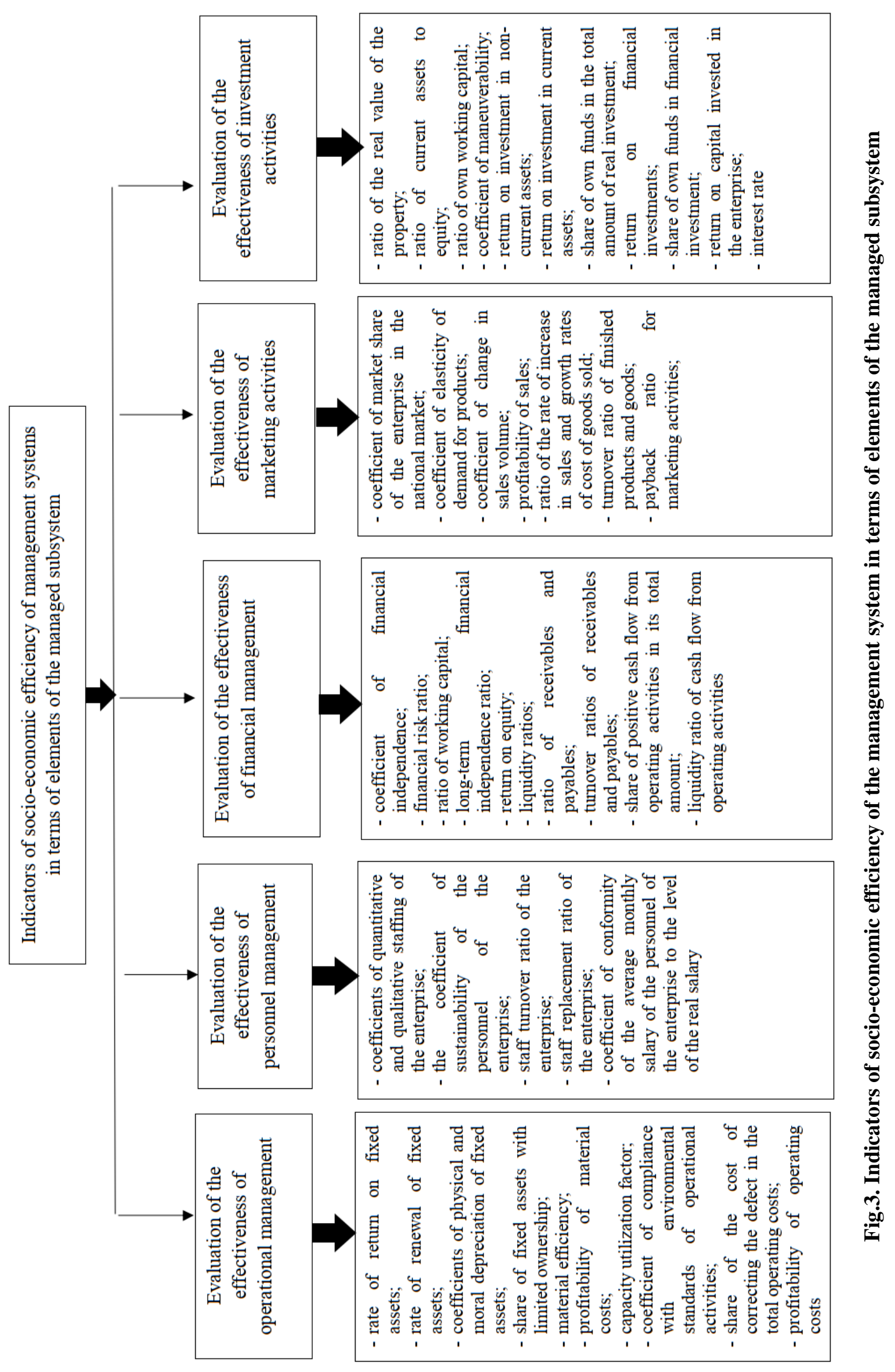


Socio-economic efficiency of the enterprise management system is manifested in the fact that all elements of this system are involved, function and are used in accordance with their purpose most effectively. The received system effect (as a result of an estimation of social and economic efficiency of management system) reflects both qualitative and quantitative characteristics of each element of management both open system, and essentially new quality which has arisen as a result of management work realized system communications and relationships. Given this, the tasks of modern management in the enterprise is the choice of key indicators for evaluating the results of its activities, which requires the definition of a system of parameters by which you can measure the final results of enterprise management.

The approach presented in the article can be applied to assess the effectiveness of sustainable development management based on European experience, where the key priority of the formation and development of management systems is to achieve sustainable development goals by implementing socially responsible behavior in the environment.

\section{REFERENCES:}

1. Armstrong M. (2015). Armstrong's Handbook of Performance Management: An Evidence-Based Guide to Delivering High Performance. London: Kogan Page. 416 p.

2. Armstrong M. (2005). Managing Performance: Performance Management in Action. London: Chartered Institute of Personnel and Development. 192 p.

3. Biliyavskiy V., Biliavska J. (2014). Evaluation of personal career management efficiency of trade enterprise employees. Canadian Journal of Scienceand Education: journal. Toronto. № 2 (6). P. 684695. Available at: http://er.nau.edu.ua/handle/NAU/31345

4. Dejneko O. (2006). Efficiency and quality of management of the machine-building enterprise. Kiev: Mechanical engineering. $24 \mathrm{p}$.

5. Goncharuk A.G. (2011). Formation of the mechanism of enterprise performance management: a case of the food industry of Ukraine. Saarbrücken: Lambert Academic Publishing. 306 p.

6. Graham J. (2004). Developing a Performance-Based Culture. Journal for Quality and Participation. Vol. 27, № 1. P. 4-8.

7. Griffith, Glenn E.; Omernik, James M.; Wilton, Thomas F.; and Pierson, Suzanne M. (1994) "Ecoregions and Subregions of Iowa: A Framework for Water Quality Assessment and Management," Journal of the Iowa Academy of Science: JIAS, 101(1), 5-13. Available at: https://scholarworks.uni.edu/jias/vol101/iss1/4

8. Heathfield S.M. (2014). Performance Management Is NOT an Annual Appraisal. Available at: http://humanresources.about.com/od/performanceevals/a/performancemgmt_2.htm. 245 p.

9. Houldsworth E., Jirasinghe D. (2006). Managing and Measuring Employee. London: Kogan Page.

10.Hutchinson S. (2013). Performance Management: Theory and Practice. London: Chartered Institute of Personnel and Development. 328 p.

11.Korytska O. (2014). Therminalogical aspects of business evaluation: effect, effectiveness, efficiency. Economics and Management, No. 2 (38), pp. 15-19.

12.Lala O. (2008). Otsinka yakosti systemy upravlinnya pidpryyemstvom: monohrafiya [Quality assessment of enterprise management system: monograph], PUSKU, Poltava, Ukraine.

13.Levchuk T., Kryvov"yazyuk I. (2017). Problemy zabezpechennya efektyvnosti diyal'nosti pidpryyemstva ta yikh vyrishennya $\mathrm{v}$ suchasnykh kontseptsiyakh hospodaryuvannya. Naukovyy visnyk Khersons'koho derzhavnoho universytetu. Vypusk 23. Chastyna 2. P. 50-53.

14.Lyzunova O., Pukhanov O. (2017). Zabezpechennya efektyvnosti diyal'nosti pidpryyemstva. Naukovyy visnyk Uzhhorods'koho natsional'noho universytetu. Vypusk 12. Chastyna 1. P. 187-190.

15. Montgomery J. (2000). Quality assessment and improvement processes and techniques. Paper presented at Project Management Institute Annual Seminars \& Symposium, Houston, TX. Newtown Square, PA: Project Management Institute.

16.Neely A. (2011). Business Performance Measurement: Unifying Theory and Integrating Practice. Cambridge: Cambridge University Press. 528 p.

17.Pakulin S., Pakulina A. (2016). Upravlinnya stalym rozvytkom suchasnoho pidpryyemstva. Élektronnyy nauchnyy zhurnal. № 3(8). Available at: https://core.ac.uk/download/pdf/42122781.pdf 
18.Sadyekov A., Shtal' T. (2011). Otsinka yakosti upravlinnya yak faktor uspishnoyi realizatsiyi stratehiyi pidpryyemstv restorannoho hospodarstva. Ekonomika kharchovoyi promyslovosti. № 2. P. 57-61. Available at: http://nbuv.gov.ua/UJRN/echp_2011_2_14.

19.Taran-Lala O. (2016), Funktsionuvannya sotsial'no-ekonomichnykh system: teoriya ta praktyka: monohrafiya [Functioning of socio-economic systems: theory and practice: monograph], PUET, Poltava, Ukraine.

20. Taran-Lala O. (2018), Metodolohiya ta praktyka funktsionuvannya ta rozvytku spozhyvchoyi kooperatsiyi Ukrayiny: monohrafiya [Methodology and practice of functioning and development of Consumer Cooperation of Ukraine: monograph], PUET, Poltava, Ukraine.

\section{УДК UDC 656.073.7}

JEL: M38

Комеліна Ольга Володимирівна, доктор економічних наук, професор. Гунченко Марія Володимирівна, кандидат економічних наук, доцент. Національний університет «Полтавська політехніка імені Юрія Кондратюка». Оцінювання та регулювання соціально-економічної ефективності систем управління. Стаття присвячена вирішенню проблем розвитку теоретичних та методичних основ оцінювання та регулювання соціально-економічної ефективності систем управління в сучасних умовах господарювання. Проведено аналіз сучасних теоретичних досліджень у цій сфері. Зроблено висновки щодо відсутності універсального підходу до оцінювання соціальноекономічної ефективності систем управління. Пропонується: дотримуватися логіки системного підходу до розуміння сутності та змісту підприємства, узагальнення показників соціальноекономічної ефективності системи управління відповідно до структурних компонентів контролюючої та керованої підсистем. Запропонована система показників соціально-економічної ефективності системи управління, що включає комплексну оцінку використання всіх ресурсів підприємства $\mathrm{i}$ містить усі загальноекономічні показники.

Ключові слова: система управління, соціально-економічна ефективність, системний підхід в управлінні, оцінювання якості управління, показники ефективності.

UDC 656.073.7

JEL: M38

Komelina Olha, Doctor of Sciences (Economics), Professor. Hunchenko Mariia, PhD (Economics), Associate Professor. National University «Yuri Kondratyuk Poltava Polytechnic». Evaluation and Regulation of Socio-Economic Efficiency of Management Systems. The article is devoted to solving problems of development of theoretical and methodical bases of estimation and regulation of social and economic efficiency of management systems under modern conditions of management. The analysis of modern theoretical researches in this field is carried out in the work. Conclusions are made on the lack of a universal approach to assessing the socio-economic efficiency of management systems. It is offered: keeping the logic of the system approach to understanding the essence and content of the enterprise, to generalize the indicators of socio-economic efficiency of the management system in accordance with the structural components of the control and managed subsystems. The proposed system of indicators of socio-economic efficiency of the management system gives, including a comprehensive assessment of the use of all resources of the enterprise and contains all general economic indicators.

Key words: management system, socio-economic efficiency, system approach in management, management quality assessment, efficiency indicators. 